\title{
TRANSFORMASI “ALFU LAILAH WA LAILAH”
}

\author{
Eva Farhah 1,2 \\ ${ }^{1}$ Program Studi Sastra Arab Fakultas Ilmu Budaya \\ Universitas Sebelas Maret Surakarta \\ 2Email: evafarhah@staff.uns.ac.id
}

\begin{abstract}
This research tries to discover and reveal the transformation works from "Alfu Lailah wa Lailah". The purpose of the discovery and disclosure of the works of transformation is to know the reader's attitude to the work "Alfu Lailah wa Lailah". The theory used in this research is intertextual theory with descriptive qualitative research method. The results show that the work "Alfu Lailah wa Lailah" has inspired writers, musicians, and choreographers, and literary enthusiasts to give birth to other similar works. The work of transformation in the form of prose found a number of 12 manuscripts, in the form of music of a number of 2 works, in the form of choreography of ballet 1 , and in the form of film and animated film totaling 3 film.
\end{abstract}

Keywords: Work, Transformation, Alfu Lailah wa Lailah, Intertextual.

$$
\begin{aligned}
& \text { ملخص } \\
& \text { يهدف هذا البحث إلى كشف ووصف الأعمال المحولة من عمل ألف ليلة وليلة التى يتمكن من خلال هذا } \\
& \text { الكشف أن يسلط هذا البحث الضوء على موقف القارئين بحاه عمل ألف ليلة وليلة. ويستخدم هذا البحث } \\
& \text { نظرية الثناص على المنهج الوصفي. وتدل نتائج البحث على أن عمل ألف ليلة وليلة قد ألم الأدباء والموسيقيين }
\end{aligned}
$$

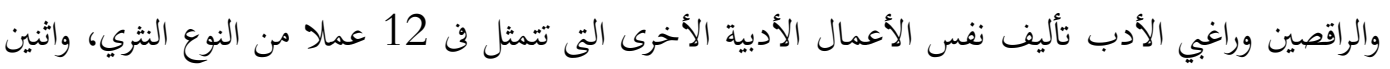

$$
\begin{aligned}
& \text { من النوع الموسيقي ، وواحد من نوع عمل الرقص، وثلاثة من نوع الفيلم والفيلم الرسومي. } \\
& \text { الكلمات المفتاحية : العمل الأدبي، التحويل، ألف ليلة وليلة، التناص. }
\end{aligned}
$$

\section{A. Pendahuluan}

Dalam artikel ini, masyarakat Arab dilihat sebagai sebuah masyarakat yang memiliki kecenderungan kuat pada ekspresi spontan, sensitivitas yang dalam, serta terpesona pada puisi, imajinasi, metafora, dan simbolisme (bdk. Barakat, 2012: 277). Kecenderungankecenderungan tersebut di antaranya nampak dalam karya "Alfu Lailah wa Lailah", yaitu sebuah narasi klasik yang mendapatkan tanggapan dari para pembacanya, dari masa ke masa. "Alfu Lailah wa Lailah" adalah salah satu karya sastra Arab monumental yang merepresentasikan sepenggal kehidupan masyarakat dan budaya Arab pada zaman keemasan Daulah Abassiyah (750 H-1258 M) (Noor, 2014: 160). Penceritaan yang terus berlangsung dan dilakukan oleh para pembaca dari masa ke masa menjadikan karya ini abadi.

"Alfu Lailah wa Lailah" juga digolongkan dalam karya garda depan (Masterpiece). Sebagimana disebutkan oleh Frank N. Magill dalam bukunya yang berjudul Masterpieces of World Literature (1817); 
This group of tales, more properly called the thousand and one night, was passed down by word of mouth in many lands throughout the East and was eventually formalized and standardized by bazaar storytellers. Most scholars believe that the collection took its present from in Cairo in the fifteentn century; it was introduced to the West in Antoine Gallad's 1704 translation published in Paris....(Magill, 1817: 51).

[Kelompok cerita ini, yang lebih tepat disebut seribu satu malam, diturunkan dari mulut ke mulut di banyak negeri di seluruh Timur dan akhirnya diformalkan dan dibakukan oleh pendongeng bazar. Sebagian besar ilmuwan percaya bahwa koleksi tersebut hadir di Kairo pada abad ke lima belas; itu diperkenalkan ke Barat dalam terjemahan Antoine Gallad 1704 yang diterbitkan di Paris.... (Magill, 1817: 51)].

Dari pernyataan Magil tersebut di atas, dapat dipahami bahwa kisah "Alfu Lailah wa Lailah" telah tersebar ke penjuru dunia, dari mulai dunia Timur, hingga ke Barat. Sehingga, memungkinkan karya tersebut dibaca, dicerap, dinikmati dan diadopsi oleh para peminat kisah. Luasnya pengaruh karya ini terus menyebar hingga ke periode modern dalam periodisasi sastra Arab. Pada masa modern ini, muncul karya-karya sastra Arab yang kelahirannya terinspirasi dari karya "Alfu Lailah wa Lailah". Dengan demikian, penelitian tentang karya transformasi "Alfu Lailah wa Lailah" perlu dilakukan. Alasan perlu dilakukannya penelitian ini adalah untuk memetakan dan merunut penelitian terkait "Alfu Lailah wa Lailah" sehingga dapat diketahui hasil yang telah diperoleh. Selain itu, isi dari kisah tersebut mengandung pesan-pesan moral yang masih relevan dengan kondisi masyarakat modern saat ini. Penelitian ini juga merupakan sebuah bukti dedikasi peneliti terhadap keilmuan yang ditekuni, pentingnya karya besar atau master (dalam hal ini: "Alfu Lailah wa Lailah") dikaji secara terinci dan menyeluruh karena karya tersebut dapat menginspirasi para sastrawan dan peminat sastra untuk melahirkan karya-karya serupa, serta munculnya karya-karya sejenis yang mengadopsi unsur-unsur yang terdapat di dalam suatu karya sastra (karya hipogram).

Sejumlah penelitian terdahulu terkait Alfu Lailah wa Lailah telah dilakukan, tepatnya di tahun 1985, 2009, 2014, 2015, 2016. Namun demikian, sejumlah penelitian tersebut tidak dapat menjawab permasalahan yang ada dalam penelitian ini. Permasalahanpermasalahan yang telah diteliti adalah tentang perkembangan kisah "Alfu Lailah wa Lailah" yang terdapat di dunia barat. Sehingga, sejumlah karya berjudul "Alfu Lailah wa Lailah" bermunculan di dunia barat dengan sejumlah kisah-kisah tambahan dari tradisi barat (Pellat, 1985). Sebagai contoh konkrit yang telah diteliti adalah pengaruh dari karya sasrta Arab, yaitu hikayat "Sindibad" yang terdapat dalam "Alfu Lailah wa Lailah" terhadap karya "Robinson Krusoe", dalam tradisi barat melalui studi perbandingan. Hasil penelitiannya menunjukkan bahwa hikayat "Sindibad" menginspirasi lahirnya karya sejenis yaitu "Robinson Krusoe" (Husna, 2009). Isi dari karya "Robinson Krusoe" pun serupa dengan karya "Sindibad", yaitu berisi kisah-kisah petualangan yang dilakukan oleh seorang tokoh yang diwadahi dengan nama Sindibad. Petualangan dalam kaitannya dengan hubungannya dengan negeri asing dan petualangan tentang kepribadian masyarakat asing. Beberapa tahun kemudian, "Alfu Lailah wa Lailah" diteliti kembali dalam kaitannya dengan struktur teks naratif. Struktur penceritaan yang terdiri atas tiga bagian utama, yaitu bagian cerita pembukaan, bagian cerita isi, dan bagian cerita penutup (Sangidu, 2014). Pada bagian awal dikisahkan awal mula terjadinya kisah "Alfu Lailah wa Lailah". Prolog kisah didahului dengan kisah antara 2(dua) Raja bersaudara yang diakhiri dengan konflik hingga munculnya bagian kedua yaitu tentang kisah "Alfu Lailah wa Lailah". Kisah ini memiliki 
berbagai versi, versi lain menyebutkan berisi 300 (tiga ratus) kisah, dan versi lain berisi 250 (dua ratus lima puluh) kisah, dan bagian terakhir yaitu berisi kisah penutup yang kembali ke kisah awal, yaitu ke kisah 2(dua) Raja bersaudara yang diakhiri dengan akhir yang membahagiakan tokoh-tokohnya. Satu tahun kemudian, diteliti kembali mengenai simbol-simbol yang terdapat dalam "Alfu Lailah wa Lailah" dalam kaitannya dengan ajaran Islam (Rokib, 2015). Simbol-simbol yang ditemukan kemudian dimaknai dan dikaji, sehingga terungkaplah makna-makna yang terkandung dan menunjukkan pada ajaranajaran Islam.

Meskipun telah dilakukan sejumlah penelitian terkait objek penelitian "Alfu Lalilah wa Lailah", namun demikian penelitian tersebut belum dapat menjawab permasalahan dalam penelitian ini. Sehingga tujuan dari penelitian ini adalah untuk menemukan karya-karya transformasi dari karya "Alfu Lailah wa Lailah", dalam berbagai bentuknya. Sehingga dapat diketahui sejarah kemunculan dan perkembangan karya tersebut. Adapun yang dimaksud dengan karya-karya transformasi di sini adalah karya-karya yang dilahirkan setelah munculnya karya mula (pertama) dalam berbagai genrenya.

\section{B. Teori dan Metode Penelitian}

Untuk menemukan karya transformasi dari karya hipogram yang berjudul "Alfu Lailah wa Lailah" ini, dimanfaatkan teori intertekstual. Teori intertektual ini dapat dipahami sebagai sebuah kajian yang memandang bahwa sebuah teks itu berasal dari hubungan antara "karya baru" dengan "karya terdahulunya". Artinya, suatu karya sastra dalam hal ini "Layali Alfu Lailah" tidak akan memiliki arti, kecuali hanya dalam hubungannya dengan karya yang lain, yaitu karya "Alfu Lailah wa Lailah". Sehingga, karya "Layali Alfu Lailah" dapat diinterpretasikan (bdk, Sangidu, 2005:25). Hubungan antar kedua karya tersebut dapat berupa kata, seperti pada penamaan tokoh dan nama tempat yang terdapat di dalam 2(dua) karya tersebut; "Syahrazad, Dunyazad atau Dinazad, Syahrayar, kerajaan", dan lain sebagainya. Dapat pula berupa hubungan frasa, kalimat, ataupun masalah yang terdapat di dalam karya sastra. Pengungkapan hubungan di antara kedua karya sastra tersebut dapat dilakukan dengan cara menguraikan "tradisi" yang terdapat di dalam karya sastra. Tradisi di sini dipahami sebagai sebuah kegiatan peniruan suatu karya sastra baru dari karya sastra yang muncul sebelumnya. Dengan demikian, kegiatan peniruan ini hanya dapat dilakukan setelah pembaca dalam posisinya sebagai pengarangmembaca karya-karya sebelumnya (Harold Bloom dalam Culler, 1981:107109). Maka, setelah membaca atau mendengarkan kisah "Alfu Lailah wa Lailah", Taufiq al-Chakim dapat menciptakan karya teks drama berjudul "Syahrazad" (1934), Ali Achmad Bakatsir menciptakan karya teks drama berjudul "Sirru Syahrazad" (t.t.), Najib Machfudz menciptakan karya prosa berjudul "Layali Alfu Lailah" (2014) dan pengarangpengarang dari Barat.

Selanjutnya, metode yang diterapkan dalam penelitian ini adalah metode kualitatif deskriptif. Pemanfaatan metode kualitatif ini karena mempertimbangkan bahwa metode kualitatif dipandang dapat menyesuaikan diri apabila berhadapan dengan kenyataan ganda (antara karya sastra dan dunia nyata) (bdk. Moleong, 2004: 5). Metode kuliatatif dapat dipahami sebagai metode yang menitikberatkan hasil kajiannya pada kualitas penelitian yang disuguhkan. Adapun yang dimaksud dengan deskriptif adalah bahwa data-data yang dikumpulkan berupa uraian kata-kata atau deskripsi gambar dan bukan angka-angka. Tujuan penelitian deskriptif sendiri adalah untuk membuat pecandraan secara sistematis, faktual, dan akurat mengenai fakta-fakta dan sifat-sifat populasi atau tempat tertentu (Moleong, 2004: 6; Suryabrata, 1995: 18). Dengan demikian, penelitian terhadap karya-karya transformasi "Alfu Lailah wa Lailah" dapat dirunut berdasarkan kemunculannya. Hal ini 
merupakan capaian yang harus dicapai dari penelitian ini.

\section{Pembahasan dan Hasil \\ 1. "Alfu Lailah wa Lailah" sebagai Karya Hipogram}

Melalui karya sastra, kesadaran sejarah dan penghayatan religious ditanamkan secara mendalam dalam di lubuk hati manusia, dan melalui karya sastra pula nilai-nilai, pandangan hidup dan gambaran dunia (weltanschauung) Islam disebarkan kepada khalayak luas (bdk. Muthari, 2016: 13). Demikian halnya dengan yang terjadi pada karya "Alfu Lailah wa Lailah". Kisah "Alfu Lailah wa Lailah" merupakan cerita yang tidak diketahui pengarangnya, anonim (unknown), dengan jenis plot roman petualangan, settingnya di India, Persia, Arab, dan China (Magill, 1817: 51). Majdi Wahbah dan Kamil al-Muhandis (1984: 22) menyebutkan bahwa "Alfu Lailah wa Lailah" merupakan jenis sastra pelarian (escapist literature (eng); Adabul-Hurub (arab) karena karangan cerita-cerita ini dimaksudkan untuk melupakan kesedihan pembacanya atau pendengarnya, kemudian membawa pembaca atau pendengar ke alam hayalan dan imajinasi karena cerita tersebut tidak dapat dijumpai di dunia kenyataan. Pendapat tersebut tidak disalahkan karena cerita ini merupakan jenis cerita berbingkai dan imajinatif. Dimulai dari cerita utama tentang kehidupan Raja Syahrayar dan Raja Syahzaman dengan masing-masing konfliknya. Kemudian dibingkai dengan cerita-cerita yang disampaikan oleh Syahrazad kepada Raja Syahrayar dan berakhir dengan akhir kehidupan yang membahagiakan.

"Alfu Lailah wa Lailah" merupakan karya sastra timur tengah monumental yang muncul pada abad pertengahan. Cerita lisan ini kemudian berkembang (dikisahkan dari mulut ke mulut) dan dibukukan, kemudian muncul transkripsi pertamanya pada abad ke-19 di Kairo. Kemudian disadur lagi dalam bahasa Perancis oleh seorang orienalis Perancis yang bernama Antoine Gallad dan diterbitkan di Perancis pada tahun
1704 (Magill, 1817:51). Penceritaan dan kemasyhuran kisah "Alfu Lailah wa Lailah" ini menjadikan karya ini memiliki beragam saduran dalam bahasa asing lainnya. Sadurannya dalam bahasa Inggris disebut dengan "The Thousand Nights and One Night", "The Arabian Nights", "The Book of The Thousand Nights and One Night" dalam bahasa Arab terkenal dengan judul "Alfu Lailah wa Lailah", dalam bahasa Parsi "Hazar Asfanah" yang berarti "Seribu Mitos", dalam bahasa Indonesia "1001 Malam", dan cerita yang sama dalam versi bahasa Thailand serta Eropa (Saragoza).

Sturktur penceritaan "Alfu Lailah wa Lailah", berdasarkan struktur naratifnya terdiri atas 3(tiga) bagian besar. Bagian pertama berisi tentang pendahuluan cerita, pengenalan suasana atau setting penceritaan dengan sejumlah tokoh; Raja Syahrayar, Raja Syahzaman, Perdana menteri kerajaan, para pengawal raja, Isteri raja Syahrayar, Istri raja Syahzaman. Bagian kedua, berisi awal munculnya konflik dalam setiap peristiwa, konflik semakin menanjak dan peleraian konflik dengan munculnya Syahrazad yaitu putri perdana menteri yang menyerahkan dirinya untuk dijadikan sebagai istri sang raja untuk mengakhiri kekejaman sang raja. Dengan demikian, dimulailah penceritaan kisah-kisah fantasi selama seribu satu malam. Bagian terakhir, kembali sebagaimana dalam keadaan semula, kepercayaan raja Syahrayar telah kembali tumbuh terhadap perempuan. Kehidupan RajaSyahrazar dan Shyahrazad berjalan dengan damai dalam kepercayaan, cinta, dan kasih sayang di antara keduanya.

\section{2. "Alfu Lailah wa Lailah" dan Karya- karya Transformasi}

Sejumlah karya telah ditemukan dan ditentukan sebagai karya-karya transformasi atas karya "Alfu Lailah wa Lailah". Penemuan dan penentuan ini didasarkan atas kerja penelitian, pelacakan, penelurusan dan perunutan tahun kemunculan karya-karya tersebut. Karya "Alfu Lailah wa Lailah"dalam versi Arab mendapatkan sejumlah sambutan 
pembacaan dari masa ke masa dengan beragam variasi dan genre sesuai semangat zamannya. Landasan awal dalam versi Arab ini dimulai pada masa kejayaan Islam di bawah kepemimpinan Daulah Abbasiyyah (750-1258 M/132-656 H) (Poeradisastra, 2008:15; Al-Baqa'i, 2006:191). Tepatnya pada abad ke-10 karya ini tersebar ke wilayah Asia Barat Daya dan kemudian ke Eropa.Secara rinci dapat dijelaskan; Pada tahun $1450 \mathrm{M}$ merupakan tahun penulisan versi terakhir "Alfu Lailah wa Lailah" dalam bahasa Arab. Selanjutnya, pada tahun 1548 M diperoleh naskah kisah tersebut yang kemudian menjadi patokan bagi pengalihbahasaan ke dalam bahasa Perancis dan bahasa Inggris. Pada tahun 1647 M terjemahan pertama dilakukan oleh Antoine Galland dalam bahasa Perancis, diterbitkan di Paris pada tahun 1704-1717 M dalam 15(Lima belas) jilid. Dalam penerjemahan pertama ini, Antoine Galland mencampurkan kisahnya dengan menambahkan tradisi-tradisi dalam kisah khas Perancis. Ini adalah terjemahan pertama dalam masa transisinya dari bahasa Arab ke bahasa Perancis.

Setelah diterjemahkan ke dalam bahasa Perancis, kemudian pada tahun 1792 M karya tersebut diterjemahkan ke dalam bahasa Inggris oleh R. Heron dan dikemas menjadi 4(Empat) jilid. Pada tahun $1795 \mathrm{M}$, diterjemahkan kembali dalam bahasa Inggris oleh W. Beloe dalam 4(Empat) jilid buku. Naskah Arab yang diterjemahkan oleh R. Heron dan W. Beloeke dalam bahasa Inggris merupakan naskah yang ditemukan pada tahun 1548 M. Dalam perkembangan selanjutnya, pada tahun $1835 \mathrm{M}$ ditemukan kembali terjemahan terakhir dalam bahasa Arab versi lain yang kemudian dijadikan dasar bagi penerjemahan yang dilakukan oleh E.W. Lane pada tahun $1840 \mathrm{M}$ dan diterbitkan menjadi 3(Tiga) jilid buku. Pada tahun 1882-1884 M "Alfu Lailah wa Lailah" disadur oleh John Payne, kemudian diterbitkan dalam 4(Empat) jilid buku. Di tahun 1886-1888 M disadur oleh Sir Richard Burton dalam 10(Sepuluh) jilid buku. Kemudian ditambahkan 6(Enam) jilid lainnya dengan judul
"Malam-malam tambahan" (Suplemental Nights). Kemudian di akhir tahun 1800-an yaitu tepatnya di tahun 1899-1940 M karya tersebut disadur oleh J.C. Mardrus diterbitkan di Paris dalam 16(Enam belas) jilid buku. Selanjutnya, di tahun 1934, Taufiq al-Chakim menciptakan karya dalam bentuk naskah drama berjudul Syahrazad, disusul kemudian oleh Ali Achmad Bakatsir dengan karya berbentuk naskah drama Sirru Syahrazad, dan terakhir di tahun 2014 terbit karya berjudul Layali Alfu Lailah di tulis oleh Najib Machfudz.

Transformasi dalam bentuk genre musik kisah "Alfu Lailah wa Lailah" ini pertama kali dilakukan oleh Nikolai Andreyvitsy Rimski Korsakov (18441908 M). Dia adalah seorang komposer Rusia ternama, seorang Professor komposisi musik pada konservatorium musik di St. Petersburg, yang ditampilkan pada tahun 1871 M. Dia menggubah Symphonic Suite Scherazade berdasarkan kisah "Alfu Lailah wa Lailah". Beberapa tahun kemudian, tepatnya di tahun 1882 1884 M, kisah tersebut kembali di sadur oleh John Payne dan diterbitkan dalam 4(Empat) jilid buku. Dalam versi saduran selanjutnya, kisah ini memiliki sejumlah tambahan cerita sehingga menjadi berjilidjilid buku. Tepatnya pada tahun 18861888 penyaduran dan produksi karya ini dilakukan oleh Sir Richard Burton dan menghasilkan 10 jilid buku dengan tambahan 6 jilid buku dengan judul Malam-malam tambahan (Suplemental Nights). Versi ini diikuti oleh penyadur setelahnya, yaitu J.C. Mardrus, pada tahun 1899-1940 M, diterbitkan di Paris dalam 16 jilid buku. Selanjutnya, di tahun 1934 telah terbit naskah drama berjudul Syahrazad yang ditulis oleh Taufiq alChakim. Disusul kemduian naskah drama berjudul Sirru Syahrazadyang ditulis oleh Ali Achmad Bakatsir. Karya transformasi terakhir, terbit di tahun 2014, novel dengan judul Layali Alfu Lailahditulis oleh Najib Machfudz.

20 tahun kemudian setelah penerbitan karya berjudul Malam-malam tambahan (Suplemental Nights) oleh J.C. Mardrus di tahun 1899-1940, dalam 
proses sambutan masyarakatnya, kisah "Alfu Lailah wa Lailah" ini dijadikan sebagai pengantar dalam sebuah tarian balet. Musik Rimski dijadikan sebagai koreografi Ballet K. Mommsen dalam karya seni berjudul Goethe Und 1001 Nacht, pementasan ini diselenggarakan pada tahun 1960. Hal ini menunjukkan bahwa Johann Wolfgang Von Goethe (1749-1832 M) terpengaruh oleh kisah "Alfu Lailah wa Lailah"(bdk. Poeradisastra, 2008:122-123; Magill, 1817:51-52). Demikian karya-karya transformasi yang muncul atas kisah "Alfu Lailah wa Lailah" di dunia barat dan timur.
Selain dalam transformasi dalam bentuk karya-karya penceritaan, musik, dan koreografi tari balet, muncul juga transformasi dalam bentuk film.Film pertama; The Dream of Syahrazah (2014), Sutradara François Verster.Kedua muncul film serial dengan judul Sehrazat (2015), episode 1-100, yang ditayangkan oleh stasiun televisi Indonesia ANTV. Terakhir, film kartun animasi anak oleh Vina Candrawati (2014), Rina Ariyani (2015), Nairotechno Channel (2016). Berikut ini gambar diagram transformasi "Alfu Lailah wa Lailah" berdasarkan frekuensi kemunculannya dan berdasarkan tahun kemunculannya.

Diagram 1:

Transformasi “Alfu Lailah wa Lailah” berdasarkan frekuensi kemunculan

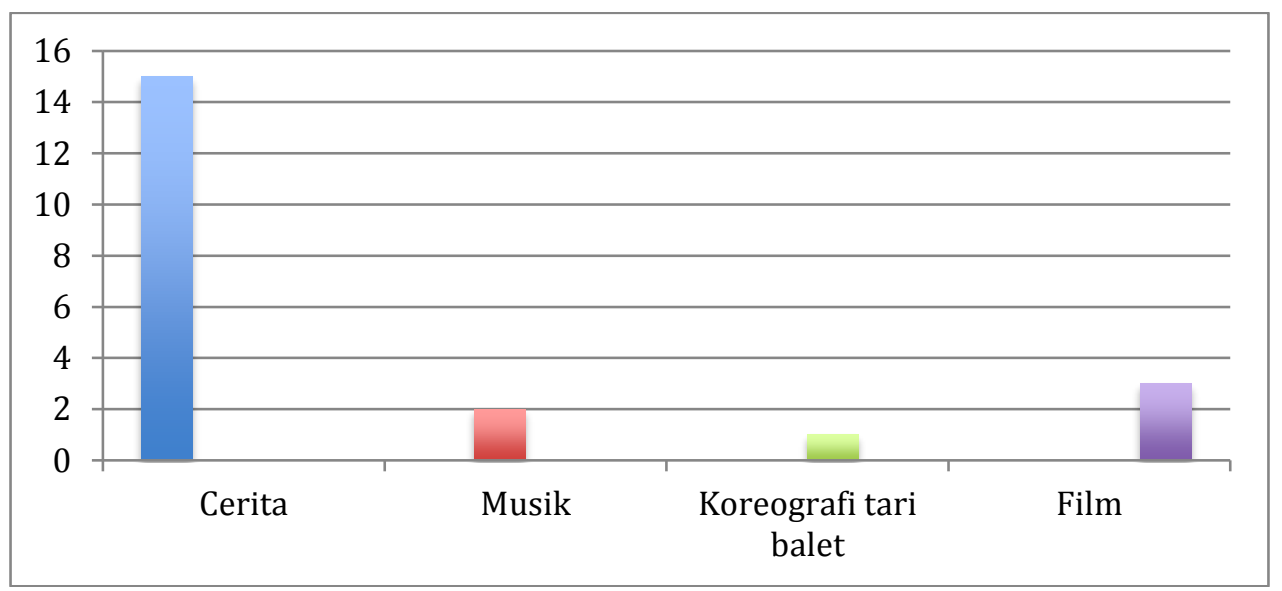

Diagram 2:

Transformasi “Alfu Lailah wa Lailah" berdasarkan prosentase tahun kemunculan

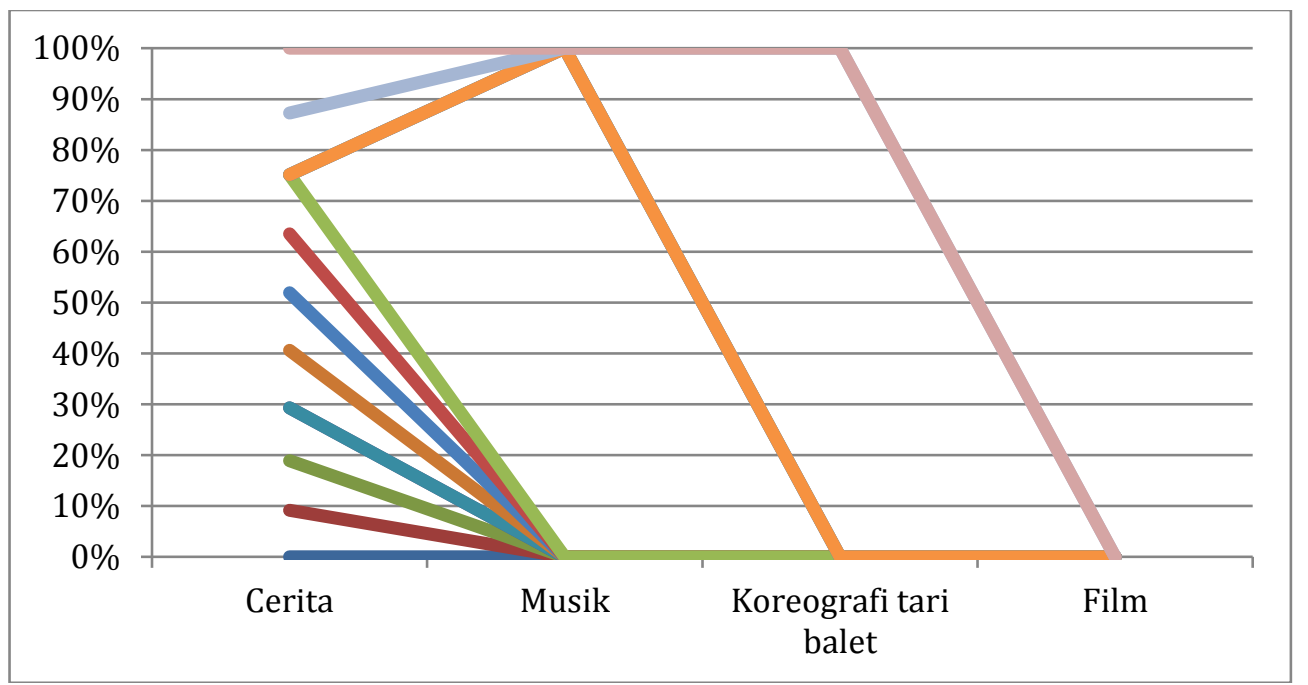


Demikian hasil penelitian yang telah dilakukan penelitian terhadap karya-karya transformasi atas karya "Alfu Lailah wa Lailah". Mayoritas karya-karya transformasi tersebut -cerita, musik, koreografi tari balet, film- memiliki struktur yang sama atau hampir sama sebagaimana karya hiporamnya. Namun demikian, terdapat 3(tiga) karya transformasi yang memiliki struktur penceritaan berbeda dari karya hipogramnya. Ketiga karya tersebut adalah naskah drama berjudul Syahrazad (1934) yang ditulis oleh Taufiq al-Chakim. Disusul kemudian naskah drama berjudul Sirru Syahrazad yang ditulis oleh Ali Achmad Bakatsir (t.t). Terakhir, novel dengan judul Layali Alfu Lailah (2014) ditulis oleh Najib Machfudz.

Perbedaan yang terdapat pada ketiga karya tersebut terdapat pada sturuktur

penceritaan dan penokohannya. Struktur penceritaan yang muncul pada ketiga karya tersebut cenderung melanjutkan kisah dari karya hipogram, "Alfu Lailah wa Lailah". Ketiga karya tersebut muncul menjadi karya-karya baru dengan tetap mewariskan setting dan alur penceritaan dari karya terdahulunya.Kemudian penokohan yang terdapat di dalam ketiga karya tersebut tetap menjaga penokohan dari kedua tokoh utamanya, yaitu Raja Syahrayar dan Syahrazad. Sedangkan tokoh pendampingnya diwadahi oleh tokoh-tokoh dan penokohan yang berbeda antara ketiga karya. Inilah transformasi yang jelas-jelas tampak dari karya hipogramnya. Di sinilah kemudian dapat ditemukan persamaan dan perbedaan antara karya hipogram dan karya transformasi, sebagaimana dapat dilihat pada gambar bagan berikut ini.

Tabel 1

Bagan persamaan antara karya hipogram dan transformasi

\begin{tabular}{|c|c|}
\hline Persamaan & Persamaan \\
\hline Karya Hipogram & Karya Transformasi \\
\hline 1. Tokoh dan Penokohan (Tokoh utama): & 1. Tokoh dan Penokohan (Tokoh utama): \\
\hline a. Raja Syahrayar & a. Raja Syahrayar \\
\hline b. Syahrazad Putri Perdana Perdana & b. Syahrazad Putri Perdana Menteri \\
\hline Menteri & c. Dunyazad/Dinazad \\
\hline c. Dunyazad/Dinazad & \\
\hline $\begin{array}{l}\text { 2. Setting (Tempat dan waktu): } \\
\text { a. Kerajaan Raja Syahrayar } \\
\text { b. Malam hari dan siang hari }\end{array}$ & $\begin{array}{l}\text { 2. Setting (Tempat dan waktu): } \\
\text { a. Kerajaan Raja Syahrayar } \\
\text { b. Malam hari dan siang }\end{array}$ \\
\hline 3. Alur Penceritaan: & 3. Alur Penceritaan: \\
\hline Alur maju & Alur maju \\
\hline
\end{tabular}

Dari bagan tersebut di atas, dapat dibaca baha terdapat unsur-unsur dalam sastra (intrinsik) persamaan dalam sejumlah unsur, yaitu tokoh dan penokohan, setting yang terdiri atas setting tempat dan waktu, dan alur penceritaan yang beralur maju. Selain adanya persamaan pada karya hipogram dan karya transformasi dalam 3(tiga) unsur intrinsik karya sastra, ditemukan pula unsur-unsur dalam sastra yang berbeda. Perbedaan ini muncul karena adanya misi pengarang atau pencipta karya sastra dalam menyampaikan pesan kepada para pembaca, sebagaimana terangkum dalam bagan berikut di bawah ini:

Tabel 2

Bagan perbedaan antara karya hipogram dan transformasi

\begin{tabular}{|c|c|}
\hline Perbedaan & Perbedaan \\
\hline Karya Hipogram & Karya Transformasi \\
\hline $\begin{array}{l}\text { 1. Tokoh dan Penokohan (Tokoh pembantu): } \\
\text { a. Permaisuri/Istri raja syahrayar } \\
\text { b. Tokoh-tokoh dalam kisah Syahrazad } \\
\text { 2. Peristiwa }\end{array}$ & $\begin{array}{l}\text { 1. Tokoh dan Penokohan (Tokoh } \\
\text { pembantu): } \\
\text { a. Permaisuri/Istri raja syahrayar } \\
\text { b. Tokoh-tokoh dalam kisah Syahrazad }\end{array}$ \\
\hline
\end{tabular}


3. Pengkisahan: Kisah berbingkai

4. Tema cerita monoton (1 hal)
2. Peristiwa

3. Pengkisahan: Kisah naratif

4. Tema cerita beragam/variatif
Pada tabel 2 tersebut di atas, dapat dipahami bahwa sejumlah unsur dalam sastra (unsur intrinsik) pada unsur tokoh dan penokohan. Pada karya hipogram dan transformasi terdapat tokoh dan penokohan selain tokoh utama, yaitu tokoh pembantu, tokoh tambahan. Peristiwa yang terjadi dalam dua karya tersebut berbeda, pada karya hipogram, peristiwa-peristiwa yang terjadi dideskripsikan dengan jelas, tanpa perlu banyak pemaknaan. Adapun peristiwaperistiwa yang terdapat pada karya transformasi berisi tentang peristiwaperistiwa yang bersifat filosofis. Artinya, peristiwa yang disuguhkan oleh pengarang masih memungkinkan lagi untuk dimaknai oleh pembacanya. Karena si pengarang menyampaikan pesan moral dan edukasi masyarakat dengan cara menyesuaikan dengan semangat zamannya, karya yang diciptakan tidak lagi bersifat menghibur atau kisah-kisah romantis sebagaimana yang terdapat pada kisah hipogramnya. Tidak menutup kemungkinan pula, bahwa pada masa mendatang kan muncul karya sejenis dengan genre atau aliran kisah yang beda. Uraian pembahasan terkait transformasi karya "Alfu Lailah wa Lailah" tersebut di atas dapat diringkas sebagaimana gambar bagan di bawah ini.

Tabel 3

Karya-karya transformasi "Alfu Lailah wa Lailah"

\begin{tabular}{|c|c|c|c|}
\hline $\begin{array}{c}\text { Prosa } \\
\text { (Teks tertulis) }\end{array}$ & Musik & $\begin{array}{c}\text { Koreografi } \\
\text { tari balet }\end{array}$ & Film \\
\hline 1) $750-1258 \mathrm{M}:$ & 1) $1844-1908 \mathrm{M}$ : & 1) $1960 \mathrm{M:}$ & 1) Film: The \\
\hline Alfu Lailah wa Lailah & Nikolai Andrey & Kisah Alfu & Dream of \\
\hline $\begin{array}{l}\text { beredar di masa Daulah } \\
\text { Abbasiah. }\end{array}$ & $\begin{array}{l}\text { Rimski Korsakov, } \\
\text { seorang Professor } \\
\text { dan komposer }\end{array}$ & $\begin{array}{l}\text { Lailah wa Lailah } \\
\text { dijadikan } \\
\text { sebagai }\end{array}$ & $\begin{array}{l}\text { Syahrazah } \\
(2014), \\
\text { Sutradara }\end{array}$ \\
\hline $\begin{array}{l}\text { 2) } 1450 \mathrm{M} \text { : } \\
\text { versi terakhir beredar }\end{array}$ & $\begin{array}{l}\text { Rusia, } \\
\text { menciptakan }\end{array}$ & $\begin{array}{l}\text { pengantar dalam } \\
\text { tarian balet }\end{array}$ & François Verster. \\
\hline dalam teks bahasa Arab. & $\begin{array}{l}\text { musik tentang } \\
\text { kisah Alfu Lailah }\end{array}$ & $\begin{array}{l}\text { dengan musik } \\
\text { rimski. }\end{array}$ & $\begin{array}{l}\text { 2) Film: Serial } \\
\text { sehrazat (2015), }\end{array}$ \\
\hline 3) $1548 \mathrm{M}:$ & wa Lailah. & Koreografer & episode 1-100, \\
\hline Naskah arab ditemukan & & Ballet K. & oleh ANTV. \\
\hline kembali, kemudian & 2) $1871 \mathrm{M}:$ & Mommsen & \\
\hline dijadikan sebagai patokan & Ditampilkannya & dalam tarian & 3) Film: Kartun \\
\hline bagi pengalihbahasaan ke & symphonic suite & berjudul "Goethe & Animasi anak \\
\hline bahasa Prancis dan & scherazade pada & Und 1001 & oleh Vina \\
\hline Inggris. & pagelaran & Nacht". Tarian & Candrawati \\
\hline & konservatorium & ini diciptakan & (2014), Rina \\
\hline 4) $1647 \mathrm{M}$ : Terjemahan & musik di St. & oleh Johann & Ariyani (2015), \\
\hline pertama dilakukan oleh & Petersburg. & Wolfgang Von & Nairotechno \\
\hline $\begin{array}{l}\text { Antoine Galland dalam } \\
\text { bahasa Prancis. }\end{array}$ & & Goethe. & Channel (2016). \\
\hline \multicolumn{4}{|l|}{ 5) 1704-1717 M: } \\
\hline \multicolumn{4}{|l|}{ Kemudian diterbitkan di } \\
\hline \multicolumn{4}{|l|}{ Paris pada tahun 1704- } \\
\hline $1717 \mathrm{M}$ dalam 15 jilid & & & \\
\hline
\end{tabular}


buku.

Terbit di Paris.

6) $1792 \mathrm{M}$ :

Diterjemahkan (naskah tahun $1548 \mathrm{M}$ ) ke dalam bahasa Inggris oleh R. Heron, menjadi 4 jilid buku.

7) $1795 \mathrm{M}$ :

Diterjemahkan (naskah tahun $1548 \mathrm{M}$ ) ke dalam bahasa Inggris oleh W. Beloe, menjadi 4 jilid buku.

8) $1835 \mathrm{M}$ :

Ditemukan naskah versi bahasa Arab lainnya.

9) $1840 \mathrm{M}$ :

Naskah tahun $1835 \mathrm{M}$

diterjemahkan dan diterbitkan menjadi 3 jilid buku oleh E.W. Lane.

10) 1882-1884 M:

Alfu Lailah wa Lailah disadur oleh John Payne, kemudian diterbitkan dalam 4 jilid buku.

11) 1886-1888 M:

Disadur oleh Sir Richard Burton dalam 10 jilid buku. Kemudian ditambahkan 6 jilid lainnya dengan judul "Malam-malam tambahan" (Suplemental Nights).

12) $1899-1940 \mathrm{M}:$

Disadur oleh J.C.

Mardrus diterbitkan di

Paris dalam 16 jilid buku.

13) 1934: Syahrazad oleh 
Taufiq al-Chakim dalam

bentuk naskah drama

14) Tanpa tahun: Sirru

Syahrazad oleh Ali

Achmad Bakatsir

15) 2014: Layali Alfu

Lailah oleh Najib

Machfudz

Dari tabel 3 tersebut di atas, dapat diketahui bahwa karya transformasi "Alfu Lailah wa Lailah" mayoritas berjenis karya sastra tulis dalam genre prosa dan drama, secara keseluruhan terdapat 15(Lima belas) karya (lih. rangkuman). Dalam genre musik terdapat 2(dua) karya dengan judul Alfu Lailah wa Lailah dan symphonic suite scherazade, dalam genre tari (koreografi tari balet) terdapat 1(satu) karya dengan judul "Goethe Und 1001 Nacht", dan dalam genre film terdapat 3(tiga) karya dengan judul The Dream of Syahrazah (2014), Serial sehrazat (2015), dan Kartun Animasi anak (2014, 2015, 2016).

\section{Kesimpulan}

Berdasarkan hasil penelitian yang telah dilakukan, ditemukan sejumlah karyakarya transformasi atas karya "Alfu Lailah wa Lailah". Karya-karya transformasi ini berbentuk prosa; baik itu dalam bentuk cerita naratif, maupun dalam bentuk naskah drama, aransemen musik, aransemen musik untuk tari balet, film serial, dan film animasi.

Dari sejumlah karya-karya transformasi tersebut ditemukan poin-poin persamaan dan perbedaan dengan karya hipogramnya. Persamaan dan perbedaan tersebut tentunya memiliki maksud yang ingin dicapai oleh penciptanya. Dengan mempertahankan tokoh-tokoh utama yang terdapat dalam karya hipogram, karya-karya transformasi tersebut dalam mempertahankan tradisi, nuansa, dan ide yang di pandang baik untuk dipertahankan dan dikembangkan. Adapun perbedaan yang dimuncukan dalam karya-karya transformasi adalah untuk mengembangkan kisah tersebut menjadi kisah baru yang tidak terputus dari kisah-kisah yang telah ada sebelumnya. Di sinilah kreatifitas pencipta dimunculkan untuk menunjukkan kebaruan yang dikandung dalam karya-karya transformasi

\section{Daftar Pustaka}

Barakat, Halim. 2012. Dunia Arab: Masyarakat, Budaya, dan Negara. Dialihbahasakan oleh Irfan M/Zakkie dari judul asli: The Arab World: Society, Culture, and State. Bandung: Nusa Media.

Culler, Jonathan. 1981. The Pursuit of Sign: Semiotics, Literature, Decontruction. London: Routlegde and Kegan Paul.

Husna, Fina Mazida. 2009. Hikayat Sinbad Fi Qishah Alfu Lailah Wa Lailah Wa Robinson Krusoe Li Daniel Defoe. $\quad$ http://digilib.uinsuka.ac.id/1649/.Diakses pada tanggal 2 februari 2018, pukul 09:00 WIB.

Noor, Yusliani. 2014. Sejarah Timur Tengah (Asia Barat Daya). Yogyakarta: Penerbit Ombak.

Magil, Frank N. 1817. Masterpieces of World Literature. New York: Harper \& Row.

Moleong, Lexy. J. 2004. Metodologi Penelitian Kualitatif. Bandung: Remaja Rosdakarya.

Muthari, Abdul Hadi Wiji. 2016. Cakrawala Budaya Islam. Yogyakarta: IRCiSoD.

Pellat, Ch. 1985. Alf Layla wa Layla. Vol. I, Fasc. $\quad 8, \quad$ pp. 831-835. 
http://www.iranicaonline.org/article s/alf-layla-wa-layla. Artile diperbaharui pada 1 Agustus 2011.Diakses pada tanggal 2 februari 2018, pukul 10.00 WIB.

Poeradisastra, Saleh Iskandar. 2008. Sumbangan Islam kepada Ilmu dan Peradaban Modern. Jakarta: Komunitas Bambut.

Rokib, Muhammad. 2015. Islamic Simbolism in Alfu Lailah wa Lailah: A Paratex Approach. Kumpulan Penelitian "Majmu'atun Buchuts", halaman 1184-1188. UIN MALIKI Press: Malang. (http://tulisanterkini.com/artikel/arti kel-ilmiah/11532-islamic-symbolsin-“alfu-lailah-wa-lailah"-a-paratexapproach.html). Diakses pada tanggal 7 september 2017, pukul 20.00 .

Sangidu. 2005. Penelitian Sastra: Pendekatan, Teori, Metode, Teknik dan Kiat. Yogyakarta: Seksi Penerbitan Sastra Asia Barat, FIB, UGM.

Suryabrata, Sumardi. 1995. Metodologi Penelitian. Cetakan kesembilan. Jakarta: PT RajaGrafido Persada.

Sumber film:

Film Mesir: https://www.google.com.pg/search?ei=wy4 EWob9JZmYvQSZ35KYCQ\&q=th e+dream+of+shahrazad\&oq $=$ the + dr eam+of+shahrazad\&gs_l=psyab.1.0.0j0i22i30k118.68761.84606.0 $.86547 .47 .41 \cdot 2 \cdot 0.0 .0 .642 .6692 .0 \mathrm{j} 15 \mathrm{j}$ $4 \mathrm{j} 2 \mathrm{j} 2 \mathrm{j} 3.26 .0 \ldots . .0 \ldots 1.1 .64 . p s y-$ ab..22.25.5624...46j0i22i10i30k1j0i 131k1j0i67k1j0i46i67k1j46i67k1j0i 46k1j33i22i29i30k1.0.QWhOpUDJ qq0

Film Turki:

https://www.google.com.pg/search?ei=Ryg EWonXC4eavQSah5vIBw\&q=film +turki+shehrazat\&oq=film+turki+s \&gs_l=psyab.1.3.017j0i22i30k113.1650004.165 6301.0.1659250.30.18.1.0.0.0.452.2 295.0j9j2j0j1.12.0...0...1.1.64.psyab..20.10.1739...0i131k1.0.ZNqpUq qivqA

Film animasi:

$$
\begin{aligned}
& \text { https://www.google.com.pg/search? } \\
& \text { ei=8icEWvLzIJWuvwSq1r64DQ\&q } \\
& \text { =film+animasi+10001+malam\&oq= } \\
& \text { film+animasi+10001+malam\&gs_1 } \\
& \text { =psy- } \\
& \text { ab.3..33i22i29i30k1.65618.82763.0. } \\
& \text { 83897.47.37.2.0.0.0.512.4979.0j13j } \\
& \text { 3j4j1j1.22.0...0...1.1.64.psy- } \\
& \text { ab..24.18.3787...0j0i22i30k1j0i67k1 } \\
& \text { j0i131k1j0i131i10k1j33i160k1.0.3T } \\
& \text { cMag6HkMo }
\end{aligned}
$$

